\title{
CHANGING NESTING HABITS OF THE CATBIRD
}

JEAN BANCROFT, 306 - 200 Tuxedo Ave., Winnipeg, Manitoba. R3P OR3.

Over the past few years I have noticed a change in the nesting habits of the Grey Catbird through watching many nests at Whytewold at the southern end of Lake Winnipeg.

In general, the nests have been rather bulky and have been made of twigs and grasses and lined with fine rootlets. They have been built about $1.2 \mathrm{~m}$ to 2.4 $m$ above the ground in thick bushes and shrubs, such as Hazelnut (Corylus), Honeysuckle (Lonicera tatarica), and/or Caragana (Caragana arborescens). ${ }^{2}$ As Hazelnut shrubs seem to flourish in abundance in this area the majority of he nests I have observed were built in clumps of these shrubs.

Two years ago I reported that I had observed two nests with pieces of plastic woven into them. ${ }^{1}$ This past summer I discovered that one catbird had picked up strips of yellow kleenex and woven them into the nest while another had picked up a strip of thin lastic from a bread-wrapper, about 10 $\mathrm{cm} \times 30 \mathrm{~cm}$ and had hung it on a branch tirectly up against the nest. Plastic had lso been woven into part of the top of he nest and acted as a sort of screen. hese man-made materials had been icked up from our garden. "String, otton and rags" have been found in fatbird nests but plastic was not menoned. ${ }^{4}$

In 1980 I discovered, for the first time, catbird sitting on a nest approximately $0 \mathrm{~cm}$ high. After the nest had been bandoned, for some reason or other, 1 as able to scrutinize it better in the lazelnut bushes and found it was twotoried. At first I thought that it might ave been parasitized by a cowbird (which I understand is a rarity), but upon examining it more closely I found nothing in the lower nest. I, therefore, came to the conclusion that the 1980 nest must have been built on top of a nest used previously.

Incidentally, I have found catbirds to be extremely wary when one is near the nest. Frequently the male gives out his loud mewing call, while the female sits motionless on the nest. In 1980 a pair of catbirds seemed to become aware of me when I was at least $7.5 \mathrm{~m}$ from the nest and commenced to give warning calls; in fact, on two occasions I thought that they were going to attack me. Many times I have been unable to establish the number of nestlings, far less see the eggs.

Godfrey does not mention trees as nesting sites for catbirds. ${ }^{3}$ I was, therefore, particularly interested to find a nest in a scrub oak about $3 \mathrm{~m}$ from the ground during the first week of August, 1980. The limb was partly entwined with Virginia Creeper (Parthenocissus inserta) so that the nest was fairly well concealed from predators. I noticed that this nest was also different in another way: it was composed mostly of plant fibres, grasses, two small pieces of white paper and a little plastic. The neat inner cup was lined with fine rootlets. There were no twigs. The nest was comparable to the one shown in Hal Harrison's book (except for the man-made materials in it. $)^{5}$ Harrison mentions that the nest is "built in dense thickets, briars, vine tangles, shrubs, low trees...." I found this nesting site and the composition of the nest even more interesting because Harrison deals only with birds' nests 
east of the Mississippi River in the United States.

The nesting site was located between two properties and was close to a rnain sidewalk, so that I was able to make frequent observations until after the nesting period. Close to a fence and just below the nesting site were some honeysuckle bushes. These berries, as well as insects, provided the brood of three with all the food they required.

Contrary to my other experiences of the adults' giving out warning calls nearly every time I visited their nests, the only time this pair made any sound whatsoever was after the brood had fledged and were being fed in the honeysuckle bushes below the nesting site. Several days later I was gratified to see that all was well with the fledglings, as I noticed an adult feeding them on the sidewalk nearby.
My experiences in observing the nesting of catbirds have been very rewarding indeed!

'BANCROFT, JEAN. 1978. Variations in bird nesting habits. Blue Jay 36(2):120.

${ }^{2}$ BUDD, A. C., and K. F. BEST. 1964. Wild plants of the Canadian Prairies. Canada Dep. Agric. Pub. 983. Ottawa.

${ }^{3}$ GODFREY, W. E. 1966. The birds of Canada. Nat. Mus. Canada, Bull. 203 Ottawa.

${ }^{4}$ HARRISON, COLIN. 1978. A field guide to the nest, eggs and nestlings of North American birds. Collins, London.

${ }^{5}$ HARRISON, H. H. 1975. A field guide to birds' nests in the United States east o the Mississippi River. Houghton Mifflin Boston.

\section{PRAIRIE NEST RECORD SCHEME}

The Prairie Nest Record Scheme report for 1980 will be available in early April. The scheme seeks data on nesting birds found in the prairie provinces and the northwest territories. Contributors write down information on a special card for every nest found. These cards are forwarded to the Prairie Nest Record Scheme at the end of the nesting season. Researchers, graduate students and government agencies make use of data on the nesting of species they are studying.

Every year some contributors who have taken part for one or more years are unable to continue. Therefore, new contributors would be appreciated for this interesting project. For information and blank nest record cards write to H. W. R. Copland, Prairie Nest Record Scheme, c/o Manitoba Museum of Man and Nature, 190 Rupert Avenue, Winnipeg, Manitoba. R3B ON2. 